\title{
Single Cell Level Survey on Heterogenic Glycopeptide and $\beta$-Lactams Resistance
}

\author{
Tomasz Jarzembowski, Agnieszka Jóźwik, \\ Katarzyna Wiśniewska and Jacek Witkowski \\ Medical University of Gdańsk, \\ Poland
}

\section{Introduction}

Traditional microbiological methods, which involve the study of populations rather than individual cells, obscure heterogeneity of microorganisms. Now this phenomenon is widely reported and study of individual cells rather than populations seems to be highly reasonable. Differences between cells can be observed, especially in bacterial biofilm structure. In the case of wide variety of cells in the mixture, flow cytometry has proved to be a successful method in investigating varied populations of cells. This technique operates essentially by monitoring bacteria in suspension flowing, so that only one cell at a time passes by a sensor. The information acquired based on size and inner complexity of particles as well as fluorescence emission following previous staining can deliver great amount of information. This process also provides an immediate assessment of cells populations.

Although more than three decades ago flow cytometry has been applied to measure bacteria (Paau et al. 1977, Bailey et al. 1977), its use in microbiology is still underestimated and far from fully utilized. One of the reasons for that is that bacteria in comparison to mammalian cells are so much more difficult to work with in terms of their size and cell structure. Nevertheless with increasingly sensitive equipment, flow cytometry is finding its utility in dealing with highly heterogeneous bacterial populations.

The best known example of heterogeneity of bacteria is antibiotic resistance (Davey et al., 2003; Falagas et al., 2008). It is defined as resistance to antibiotics expressed by a subpopulation of cells within strains susceptible to antibiotics according to traditional invitro susceptibility testing. The heteroresistance has been observed in a range of microbes, including Staphylococcus aureus, coagulase-negative staphylococci, Acinetobacter baumannii , Mycobacterium tuberculosis, Streptococcus pneumoniae, Enterococcus faecium and Cryptococcus neoformans (Alvarez-Barrientos et al., 2000). Most observations on heteroresistance reported in the literature concern staphylococci resistant to methicillin, vancomycin, and/or inhibitors of teichoic acid synthesis (Finan at all., 2002). Recently, $\beta$ lactams heteroresistance of $S$. pneumoniae and vancomycin heteroresistance of enterococci have been also reported (Hasman et al., 2006; Nottasorn et al., 2005). The mechanism of $\beta$ lactams resistance is a change in the affinity of penicillin-binding proteins or overproduction of specific penicillin-binding proteins. Williamson et al. showed that at least five PBPs had 
been found in E. faecalis. Vancomycin resistance is usually determined by one of the two related gene clusters, vanA and vanB, that encode a dehydrogenase (VanH or VanHB) and ligase (VanA or VanB). Expression of VanA- and VanB-type resistance is regulated by the VanRS and VanRBSB two-component regulatory systems, respectively (Arthur et al., 1992; Evers and Courvalin, 1996).

As flow cytometry involves the study of single cells, it is an excellent method for studying heterogeneous populations. While analyzing many more cells than by conventional cytometry, rare cell types are more likely to be detected and the results are accessible to statistical analysis. The multiparametric nature of flow cytometric measurements is also an advantage. These include differences in cell size, DNA content or antigenic properties. Additionally, many supplementary modifications of flow cytometry are used. An example is the study of heterogenic vancomycin resistance with the use of reporter system for singlecell analysis of van gene expression. In the study, plasmid containing gene coding a green fluorescent protein was constructed for fluorescence-activated cell sorter (FACS) analysis (Cormack et al., 1996).

So far flow cytometry has been found useful in general microbiology with some clinical uses, as well as in its more specific branches such as environmental (Troussellier et al., 1999) or industrial microbiology (Gunasekera et al., 2000). First attempts to use flow cytometry for bacterial detection in body fluids are dated for the 80's when a test was developed enabling E. coli detection in blood samples (Mansour et al., 1985). The approach using flow cytometry has been continued and was reported later to be successful in bile, pleural fluid, ascites and cerebrospinal fluid (Takashi et al., 2000). Lately new tools based on flow cytometry have been developed, providing detection of significant bacteriuria as well as enumeration of bacterial particles, appearing to be an effective screening method (Hiroshi et al., 2006).

The emergence of multi-drug resistant microbial strains has emphasised the need for rapid detection method of antibiotic resistance and in this case as well flow cytometry appeared to be an extremely attractive tool.

Population analysis, among others, is the golden standard for the identification of hetero resistant vancomycin intermediate Staphylococcus aureus (hVISA) due to the fact that a proportion of MRSA found to harbor hVISA can be up to $8.3 \%$. Moreover, for as yet unknown reasons, virtually all clinical E. faecalis isolates are tolerant to $\beta$-lactams and glycopeptides. Minimal inhibitory concentrations (MICs) of antimicrobials remain the same but the minimal bactericidal concentrations (MBCs) increase in tolerance.

Enterococcus faecalis usually plays a role in commensal flora in the human gastrointestinal tract. However, it can become a pathogen involved in various infections such as endocarditis, urinary tract infections, meningitis, sepsis and intraabdominal infections. It is also a leading cause of nosocomial infections, and the emergence of vancomycin- and multidrug-resistant E. faecalis in the clinical setting is of particular concern (Bizzini et al., 2009).

Here, the authors will present the analysis of heterogeneity of resistance studied by flow cytometry with use of fluorescent antibiotics binding bacterial cells and fluorescent probes targeting resistance genes. The proposal of vancomycin and methicilin heteroresistant strain model will be presented. With use of the model, results obtained for clinical E.faecalis and S.aureus strain are discussed. 


\section{Material and methods}

The study was performed on reference and clinical strains listed in Tab 1. Fourteen MRSA strains were isolated from patients of various wards of the University Clinical Centre in Gdańsk and 12 Enterococcus faecalis from patients of Kościerzyna Medical Centre. The staphylococcal strains were isolated in the hospital laboratory during the period March 2008 to March 2009 and were sent to the Microbiology Department of the Medical University of Gdańsk for epidemiological typing. One isolate per patient was included in the study. Bacteria were cultured from swabs: wound ( 4 isolates), nose ( 2 isolates) and fluids: tracheostomy tube fluid ( 3 isolates), blood ( 1 isolate), abscess fluid ( 1 isolate), pus ( 1 isolate), bronchial fluid ( 1 isolate), urine ( 1 isolate). The data about clinical recognitions were not available. The isolates were cultured on sheep blood agar and were identified as S.aureus by colony morphology, a positive plasma coagulase reaction and by biochemical tests (API, bioMerieux, France). Resistance to methicillin was primary tested using disc diffusion method with cefoxitin disc (Clinical and Laboratory Standards Institute,2006) and then was confirmed by detection of mec A gene by the Polymerase Chain Reaction (PCR) as described previously (Barski et al., 1996). DNA of bacterial isolates was extracted according to the previous report (Barski et al., 1996). For further analyses, the isolates were subcultured on nutrient broth and stored with glycerol at $-70^{\circ} \mathrm{C}$.

Spa typing and BURP analyses. The polymorphic $\mathrm{X}$ region of the protein A gene (spa) was amplified from the isolates by PCR with primers and according to procedure described by Kobayashi (1999). Spa types were determined by using Ridom Staph Type software, according to Harmsen et al (2003). The spa types were clustered into spa-CCs (clonal complexes) using the algorithm BURP - based upon repeat pattern (Rupptisch et al., 2006).

Phage typing was performed according to Blair and Williams (1961). Two sets of phages were used as follows: a basic set of 23 phages with additional phages 88,89,187 and an additional set of phages MR8, MR12, MR25, 30, 33, 38, M3, M5, 622, 56B supplied by the Central Public Health Laboratory in London for use on MRSA strains (Richardson et al., 1999). The phages were used in concentrations at routine test dilution (RTD) and 100xRTD. Reactions for phages were noted as described by Blair and Williams (1961). The phage type was defined by all the phages with strong reaction.

The susceptibility of the MRSA isolates to antimicrobial agents other than cefoxitin was determined by the disc diffusion method according to the guidelines (Clinical and Laboratory Standards Institute. 2006). The following drugs were used for test: erythromycin, clindamycin, ciprofloxacin, co-trimoxazole, tetracycline, gentamycin, vancomycin, teicoplanin, fusidic acid, rifampicin, linezolid, synercid, chloramphenicol. For isolates identified as resistant to erythromycin, but susceptible to clindamycin, D-test was performed to detect inducible clindamycin resistance. For vancomycin, additionally, the minimal inhibitory concentration (MIC) was determined by E-tests as described by the manufacturer (AB Biodisc, Sweden).

Enterococci were identified by esculin hydrolysis on Coccosel agar (bioMerieux). Species-level identification was based on rapid Strep ID (bioMerieux). Susceptibility testing was performed by following the current guidelines of the National Committee for Clinical Laboratory Standards (2002). Isolates were additionally tested for resistance to nitrofurantoin, gentamycin, amikacin, tobramycin, kanamycin, streptomycin ,neomycin, penicilin, meropenem, ampicillin, piperacilin and differentiated by antibiotic resistance pattern. 


\begin{tabular}{|c|c|c|c|c|c|}
\hline No. & Clinical source & Antibiotic resistance pattern & $\begin{array}{l}\text { Phage } \\
\text { group }\end{array}$ & Phage type & $\begin{array}{l}\text { Spa } \\
\text { type }\end{array}$ \\
\hline SA1 & Urine & Te C & III & $42 \mathrm{E} / 53 / 75 / 83 \mathrm{~A}$ & 010 \\
\hline SA1 & Nose & E Cc Cip & III & $54 / 75 / 83 \mathrm{~A}$ & 003 \\
\hline SA3 & Nose & Sensitive & $\mathrm{I} / \mathrm{V}$ & $55 / 94 / 96$ & 018 \\
\hline SA4 & $\begin{array}{l}\text { Tracheostomy } \\
\text { tube fluid }\end{array}$ & E Cc Cip & III & $47 / 54 / 75 / 83 \mathrm{~A}$ & 003 \\
\hline SA5 & Blood & Cip Te C/ & NT & - & 008 \\
\hline SA6 & Wound & Cip Te C/ & III & $53 / 83 \mathrm{~A}$ & 2065 \\
\hline SA7 & Pus & E Cc Cip Sxt Te Rf C/Ge & NT & - & 037 \\
\hline SA8 & Bronchial fluid & E Cc Cip Te Ge & NT & - & 008 \\
\hline SA9 & $\begin{array}{l}\text { Tracheostomy } \\
\text { tube fluid }\end{array}$ & E Cc Cip Te Ge & III & $47 / 54 / 75 / 83 \mathrm{~A}$ & 008 \\
\hline SA10 & $\begin{array}{l}\text { Tracheostomy } \\
\text { tube fluid }\end{array}$ & E Cc Cip C & III & $47 / 54 / 75 / 83 \mathrm{~A}$ & 151 \\
\hline SA11 & Wound & E Cc Cip & II & $55 / 71$ & 003 \\
\hline SA1 & Abscess & E Cc Cip & III & $75 / 83 \mathrm{~A}$ & 003 \\
\hline SA2 & Wound & E Cc Cip & III & $83 \mathrm{~A}$ & 003 \\
\hline SA12 & Wound & E Cc Cip & NT & - & 002 \\
\hline SA & ATCC 25923 & & - & - & \\
\hline SA & ATCC 29213 & & - & - & \\
\hline E.F & wound & Te,FM, Rf, E,CC,An,NN,K,S & - & - & \\
\hline E.F & Bronchial fluid & Te,Rf,E,CC,NN,K,N,Me,Am & - & - & \\
\hline E.F & urine & $\mathrm{FM}, \mathrm{C}, \mathrm{E}, \mathrm{CC}, \mathrm{Ge}, \mathrm{An}, \mathrm{NN}, \mathrm{K}, \mathrm{S}, \mathrm{N}$ & - & - & \\
\hline E.F & urine & $\mathrm{CC}, \mathrm{An}, \mathrm{NN}, \mathrm{K}, \mathrm{S}, \mathrm{N}$ & - & - & \\
\hline E.F & wound & FM,Cip,Ra,C,CC,An,NN,K,S,N & - & - & \\
\hline E.F & wound & $\mathrm{Te}, \mathrm{FM}, \mathrm{CC}, \mathrm{Ge}, \mathrm{NN}, \mathrm{K}, \mathrm{S}, \mathrm{N}$ & - & - & \\
\hline E.F & faeces & $\mathrm{Te}, \mathrm{FM}, \mathrm{C}, \mathrm{CC}, \mathrm{An}, \mathrm{NN}, \mathrm{K}, \mathrm{S}$ & - & - & \\
\hline E.F & wound & Te,Rf,C,CC,An,NN,K,N,P, & - & - & \\
\hline E.F & faeces & Te,Cip,Ra,C,CC,NN,K, & - & - & \\
\hline E.F & faeces & Te,Ra,CC,NN, & - & - & \\
\hline E.F & faeces & $\mathrm{Cip}, \mathrm{Ra}, \mathrm{C}, \mathrm{CC}, \mathrm{An}, \mathrm{NN}, \mathrm{K}, \mathrm{S}, \mathrm{N}$ & - & - & \\
\hline E.F & faeces & $\begin{array}{l}\text { FM,Cip,Rf,C,CC,An,NN,K,N,P, } \\
\text { Mem,Am,PIP }\end{array}$ & - & - & \\
\hline E.F & ATTC 51299 & Van-R & - & - & \\
\hline E.F & ATTC 29212 & Van-S & - & - & \\
\hline
\end{tabular}

S.A Staphylococcus aureus, E.F. Enterococcus faecalis, ICU- intensive care unit; DVA - dermatology, venerology, alergology department; E - erytromycin; Cc - clindamycin (/ -inducible resistance to macrolides); Cip -ciprofloxacin; Te - tetracycline; C - chloramphenicol; Rf - rifampicin; Sxt trimetoprim/ sulfamethoxazole; Ge - gentamicin NT - non- typable; ${ }^{\circ}$ - inhibition reaction with phages; Cc - clonal complex; MIC - minimal inhibitory concentration; Va -vancomycin; FM- Nitrofurantoin, , Gegentamycin, AN- Amikacin, NN -Tobramycin, K- Kanamycin, S-streptomycin, N- Neomycin, Ppenicilin, MeM- Meropenem, AM- Ampicilin, PIP piperacilin

Table 1. List of strains used in the study. 
For flow cytometry analysis, the isolates were grown overnight on Tryptic Soy Broth (TSB) at $370^{\circ} \mathrm{C}$ and standardized to OD $1(600 \mathrm{~nm})$. The cells were then centrifuged $5 \mathrm{~min}$ at 2500 rpm, washed and suspended in $200 \mu \mathrm{l}$ PBS buffer. The binding assay was carried out by adding solution of Bocillin @fl or vancomycin @fl respecitivelly to the cell suspension of each strain. The reaction mixtures were incubated for $30 \mathrm{~min}$ at $37{ }^{\circ} \mathrm{C}$ and centrifuged. The pellets were collected and washed three times in $1 \mathrm{ml}$ of PBS. Fluorescence of particles was determined by a FACS Scan flow cytometer (Becton Dickinson, San Jose, CA, USA).

\subsection{Optymalisation of bocillin@fl and vancomycin@fl binding}

In the previous study the relation between fluorescence and amount of used bocillin@fl was described by equation below;

$$
\mathrm{y}=4.469 \ln (\mathrm{x})+3.427, \mathrm{R}^{2}=0.944
$$

Following these results (Jarzembowski et al., 2008) and similar results obtained during study of vancomycin @fl binding (Jarzembowski et al., 2009) we stained cells by addition of $1 \mu \mathrm{g} / \mathrm{ml}$ vancomycin@fl. Because of inductive mechanism of vancomycin resistance, before staining strain was cultured in presence of $2 \mathrm{ug} / \mathrm{ml}$ vancomycin (Sigma). The reaction mixtures were incubated for $45 \mathrm{~min}$ at $370^{\circ} \mathrm{C}$ and again centrifuged. The pellets were collected and washed three times in $1 \mathrm{ml}$ of PBS. Fluorescence of particles was determined with the use of FACS Scan flow cytometer (Becton Dickinson, San Jose, CA, USA). Results of induction of reference resistant strain are shown on Fig 1.

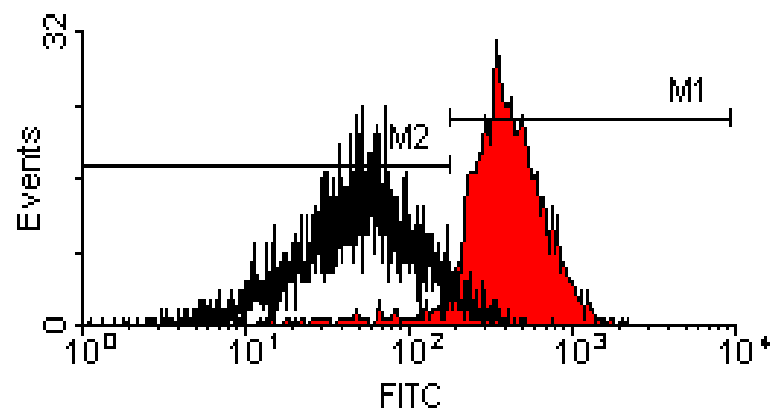

Fig. 1. Fluorescence (FL1) inducted (red) and uninducted (black) vancomycin resistant reference strain after staining with vancomycin@fl

To ensure cell nature of analysed particles we have excluded from procedure particles sized below $1 \mu \mathrm{m}$ based on value for size standard (Polysciences. Inc) and particles with low PI (propidium iodide) binding (Fig2).

\subsection{Modeling of vancomycin heteroresistant strain}

Mixture of the reference strains in proportion staring from 1.25 up to $50 \%$ of resistant cells were composed to create model of heteroresistant strain. Cells binding and not binding vancomycin @fl were differentiated by markers consisting of $99.69 \%$ of susceptible (M1) and $94 \%$ of resistant (M2) cells (Fig 3) 


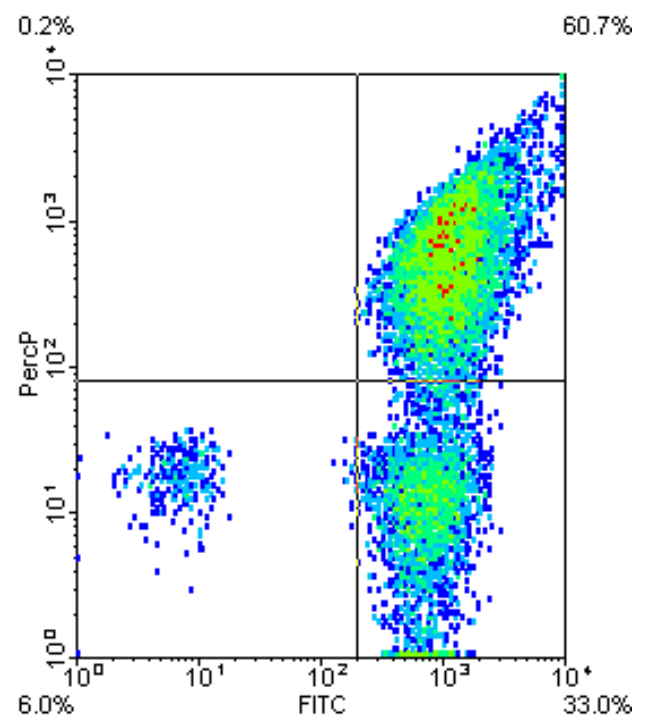

Fig. 2. Green (x axis) vancomycin@fl fluorescence and red (y axis ) PI fluorescence reference susceptible strain. Only upper regions were included into further analysis.

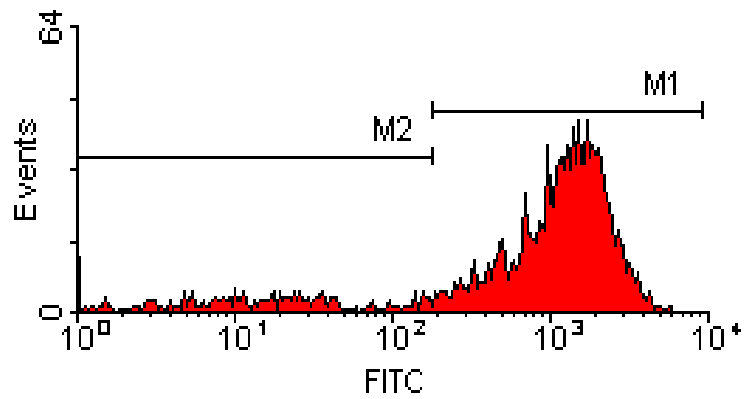

Fig. 3. Fluorescence (FL1) of mixed culture consisting of $25 \%$ resistant cells

\subsection{Design and testing of DNA probes}

Oligonucleotide probes were designed with the software package (Biosoft: Beacon Designer) and rRNA sequences were obtained from the Ribosomal Database Project (RDP) supplemented with newly deposited rRNA sequences from GenBank. As a positive control, Enfl84 probe (3'-ACGTGAGTTAACCTTTCTCC, Waar et al. 2005) targeting 16sRNA gene was used. Fluorescein-labelled oligonucleotides against selected specific target sequences (van genes) of E. faecalis were synthesized commercially (Metabion) and tested for specificity against the set of reference organisms. For hybridization, procedure described by Waar et al (2005) was adopted. Briefly, cell membrane was permeabilizated by incubation for $30 \mathrm{~min}$ at $37^{\circ} \mathrm{C}$ in permeabilization buffer consisting of $1 \mathrm{mg}$ lysozyme ml-1 (DNA Gdańsk). The cells

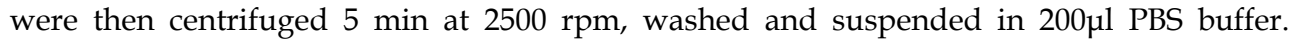


Subsequently, 200 $\mu$ l hybridization buffer containing FITC- labelled probe (1ng ) was added. The probes were hybridizated at $50^{\circ} \mathrm{C}$ for $45 \mathrm{~min}$.

\section{Results and discussion}

Heteroresistance, defined as a presence of subpopulations of resistant cells within susceptible majority was observed against $\beta$-lactams and glycopeptides. However, mechanism of actions of these groups of antibiotics is different.

The emergence of community acquired methicillin resistant Staphylococcus aureus (cMRSA) has renewed interest in the mechanisms of methicillin resistance (Okuma et al., 2002; Nunes et al., 2007). In contrast to vancomycin resistance, resistance to $\beta$-lactams (methicillin resistance) is constitutively mediated by a affinity change in penicillin-binding proteins (enzymes involved in cell wall synthesis). Because many genes are involved in cell wall biosynthesis, explanation of the nature of heterogeneous expression of methicillin resistance is very difficult (Markova et al., 2008). Since 2001, an increase in the number of MRSA strains with heteroresistance to oxacillin has been observed in the Netherlands. These strains can spread unnoticed, as their phenotypic heterogeneous resistance to beta-lactams affects the results of susceptibility testing (Wannet 2002). Coexistence of two subpopulations (susceptible and resistant) within a clinical isolate and expression of resistance only in a small number of cells leads to diagnostic problems in clinical laboratories (Markova et al., 2008). In methicillin-resistant Staphylococcus strain degree of heterogeneity is quite low: only 1 CFU of $10^{4}-10^{7}$ CFU are phenotypically resistant (De Lencastre et al., 1993).

Invention of Bocillin@fl, commercially avaible fluorescent penicillin, significantly increased possibility of studying heteroresistance (Jarzembowski et al., 2010). Results of flow cytometry were found to be correlated with reference heteroresistant strain properties. Furthermore, use of fluorescent antibiotics in flow cytometry proved linear nature of heteroresistance (Fig.4.).

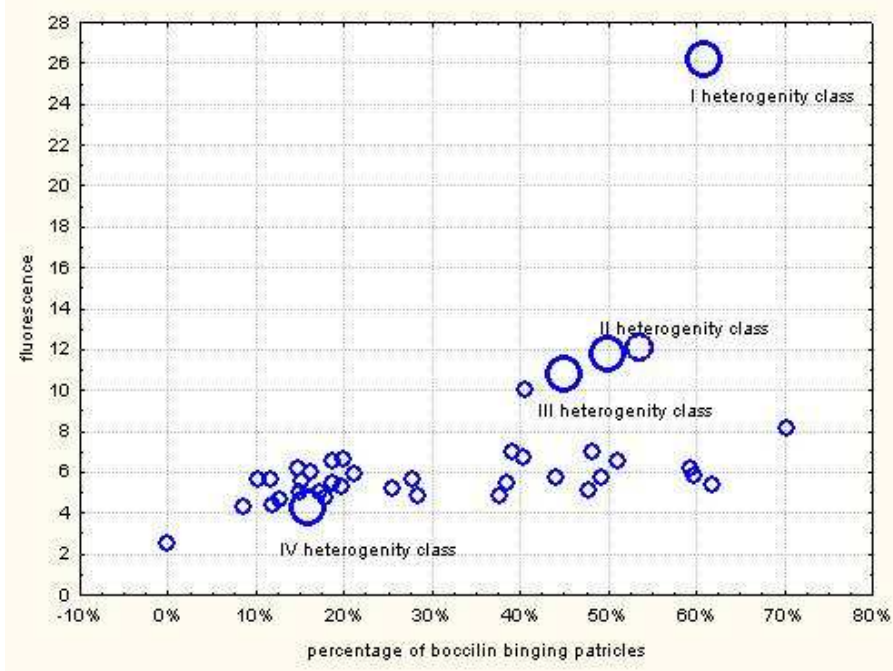

Fig. 4. Variance of bocillin @fl binding by medical isolates of S.aureus in relation to reference value 
However, even in susceptible cell culture we always detect at least $1.47 \%$ antibiotic unbinding particles so it seems that the number of resistant cells in this method is overestimated.

Results of Markova et al study (2008) showed that also changes of cell structure can be involved in mechanism of heteroresistance. Both heteroresistant and methicillin susceptible strains (MSSA) may transform into cell wall-deficient form after exposure to sub tolerant conditions. The finding that methicillin sensitive strain and heteroresistant strain give rise to L-form colonial growth both on oxacillin-free and oxacillin-containing media appeared to be remarkable. It is known that the heterogeneous resistance phenotype of mecA-positive MRSA strains progresses to homogeneous resistance upon incubation with methicillin (Sakoulas et al., 2001). Study results of resistance demonstrate that differences reduction of antibiotic binding after preincubation can be proved with the use of flow cytometry (Fig.5).

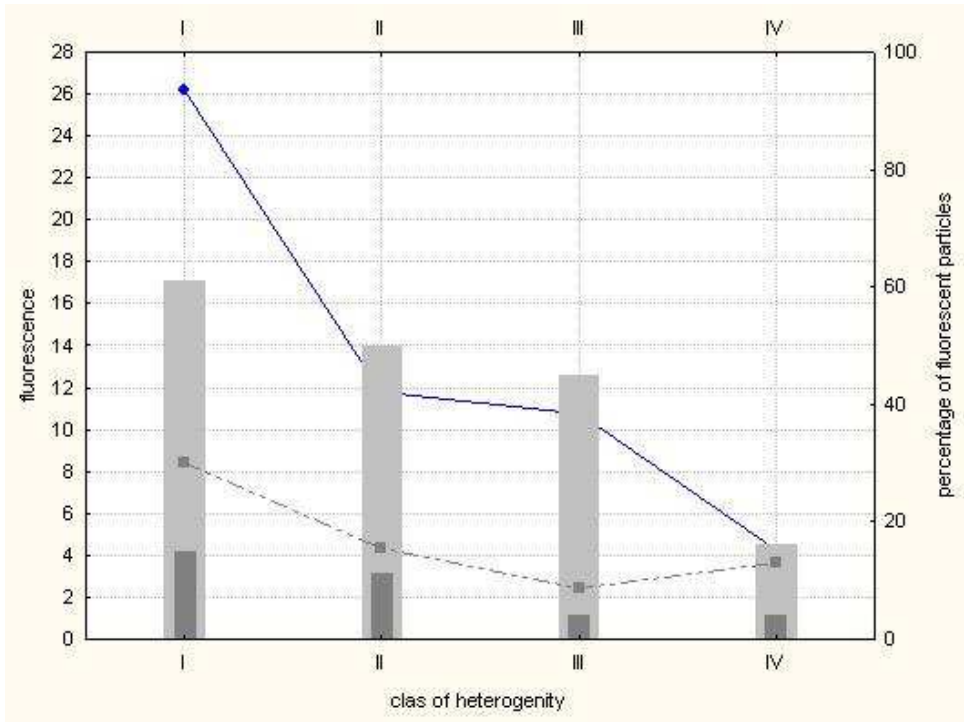

Fig. 5. Influence of incubation of heteroresistant strain with methicillin on Bocillin@fl binding

In contrast to MSSA and heteroresistant strains, homogenic MRSA strains did not convert to the cell wall-deficient forms (Markova et al., 2008).

Vancomycin resistance is an example of inductive reaction on presence of antibiotic. In presence of vancomycin high amount of cell wall precursor with low affinity to vancomycin (d-ala-d alla) is synthesized while native precursors are removed (Hasman et al., 2006). Because we aimed to detect resistant cells between susceptible majorities, the induction condition should be set to prevent inhibition of growth of susceptible strain. Thus, we set up inductive concentration below breakpoint value, at $0.016 \mu \mathrm{g} 0.8 \mu \mathrm{g}, 2 \mu \mathrm{g}$ and $4 \mu \mathrm{g} / \mathrm{ml}$. The results showed optimal induction with final vancomycin concentration of $2 \mu \mathrm{g} / \mathrm{ml}$ (data not shown). While there are no reference strains of different degree of vancomycin heteroresistance, model obtained by combination of resistant and susceptible strain was prepared. Vancomycin@fl binding by cells in this model is presented on fig 6. The high correlation between percentage of fluorescent particles and percentage of resistant cells can be seen. (Fig. 6) 


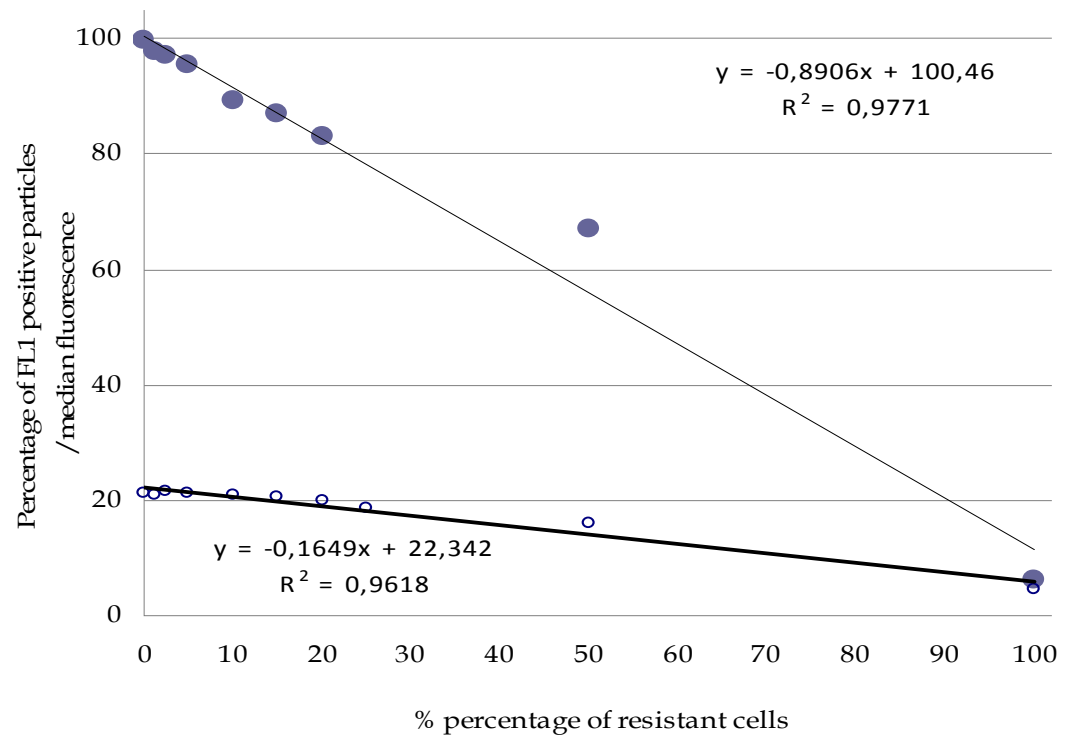

Fig. 6. Correlation between fluorescence (empty circles ), FL1 positive particle (full circles) and percentage of resistant cells

The obtained model of vancomycin heteroresistance was then used for analysis of clinical strains. The percentage of stained particles ranged from $6.07 \%$ in resistant up to $99.66 \%$ in susceptible reference strains. Percentage in resistant unindicted strains was similar to the susceptible one $(94.62 \%)$. Reference strains showed also differences in fluorescence but they were not so significant (Tab. 3.) Similar, constant divergence was observed in the study of methicillin heteroresistance (Jarzembowski et al., 2010). Despite satisfactory differentiation of heteroresistance, the results showed some limitations of the method. Even in resistant strains some particles bind vancomycin@fl according to the chosen criteria. Among clinical strains, the percentage of unstained particles varies from 46.32 to 98.53 while median fluorescence varied from 547 to 1980.96 . (Tab 2.). Generally, fluorescence of staphylococci was higher than fluorescence of enterococci

\begin{tabular}{|l|c|c|c|}
\hline & $\begin{array}{c}\text { percentage of FL1 } \\
\text { positive particles }\end{array}$ & $\begin{array}{c}\text { Median } \\
\text { fluorescence }\end{array}$ & $\begin{array}{c}\text { Mean fluorescence } \\
\text { per particle }\end{array}$ \\
\hline max in staphylococci & 97.77 & 1980.96 & 37.01 \\
\hline max in enterococci & 98.53 & 1684.85 & 27.26 \\
\hline Min in staphylococci & 46.32 & 572.55 & 10.87 \\
\hline Min in enterococci & 90.47 & 547.37 & 9.01 \\
\hline resistant reference strain & 6.07 & 239.28 & 4.6 \\
\hline Susceptible reference strain & 99.69 & 10009.04 & 21.2 \\
\hline Resistant uninducted strains & 94.62 & 403.15 & 11.5 \\
\hline
\end{tabular}

Table 2. Comparison of estimator values in groups of strains 
In contrast to results of MIC based screening of vancomycin resistance, the results obtained in flow cytometry suggest heteroresistance of some strains (Fig. 7). It is obvious if we consider that presence of heteroresistant strains in US and Europe is quite high. Nunes et al. (2007) found a prevalence of $8.5 \%$ (9/106) of glycopeptides-heteroresistant staphylococci isolated from bacteremia while others $7.4 \%$ (Frebourg et al., 1998).

None of the tested strains had a MIC value below $4 \mu \mathrm{g} / \mathrm{ml}$, so all of them should be considered as vancomycin susceptible. On the other hand, determination of MICs have shown good accuracy only to detect vancomycin intermediate Staphylococcus aureus (VISA) and fail in the detection of glycopeptides heteroresistant strains (Nunes et al., 2007). Heterogeneous phenotypes of clinical strains of S. aureus and CNS present MIC value below $4 \mu \mathrm{g} / \mathrm{ml}$ (Nunes et al., 2007). That is why heteroresistance of the strains could be missed out in routine diagnostic.

The heteroresistance has been considered responsible for failure in the treatment. Unfortunately, there is no widely accepted method to detect heteroresistant strains. The lack of a standardized method makes it difficult to determine the clinical significance in the treatment of an infection with vancomycin. In the presence of vancomycin not only van genes change expression. There is some evidence that vancomycin influences biofilm formation, at least in S. epidermidis culture. Changes of cell surface structure and size seen in flow cytometry as SSC and FSC values were explained by the studied effect of the glycopeptide antibiotic on cell envelope properties and biofilm formation. SEM examination of cells grown in the presence of vancomycin revealed the presence of polymorphic form. Such changes in cell morphology could be the reason of extremely high fluorescence of some strains after staining with vancomycin@fl.

O S.aureus

O Suceptible S. aureus

- Susceptible E.faecalis

O uninducted resistant strain

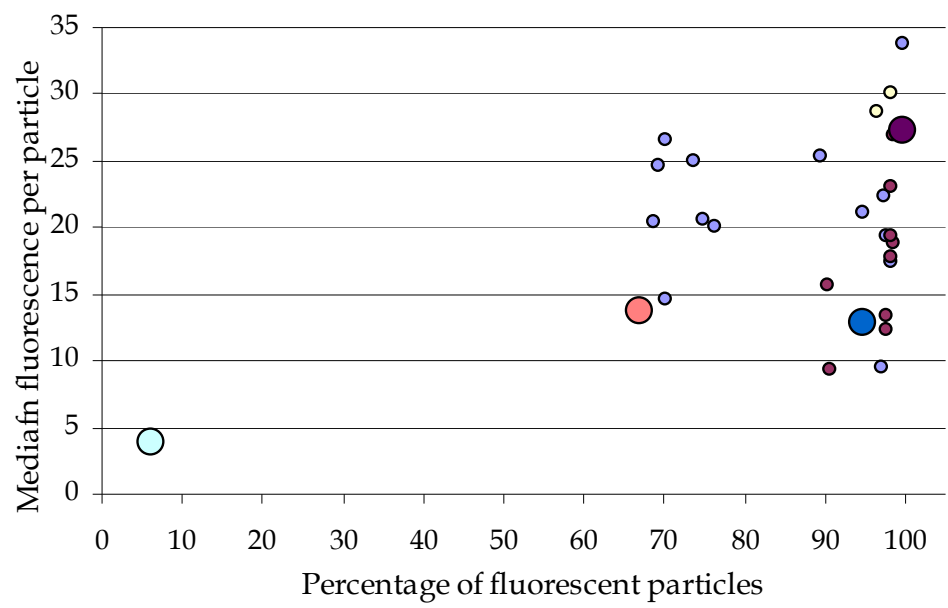

Fig. 7. Variance of vancomycin@fl binding by medical isolates of S.aureus and E. faecalis in relation to reference value 
Both in study of vancomycin heteroresistance and study of methicillin resistance, median fluorescence per particle seems to be a very effective estimator (Fig. 1, 7). It is interesting to compare FCM results of "native 'methicillin heteroresistance (Fig. 4) and "artificial' model of vancomycin heteroresistance. Despite different resistance mechanism, changes of estimators are very similar. Both fluorescence and percentage of fluorescent particle decrease with amount of resistant cells (Fig. 7).

Detailed information about mechanism of heteroresistance can be explained by the study of resistance gene expression. At the first stage of our ongoing study we adopt protocol described by Warr (2005) to detect 16sRNA gene. In fact, Fig. 8 demonstrates successful detection of E. faecalis cells in flow cytometry. Furthermore, the protocol used determines the amount of cells in mixed culture.

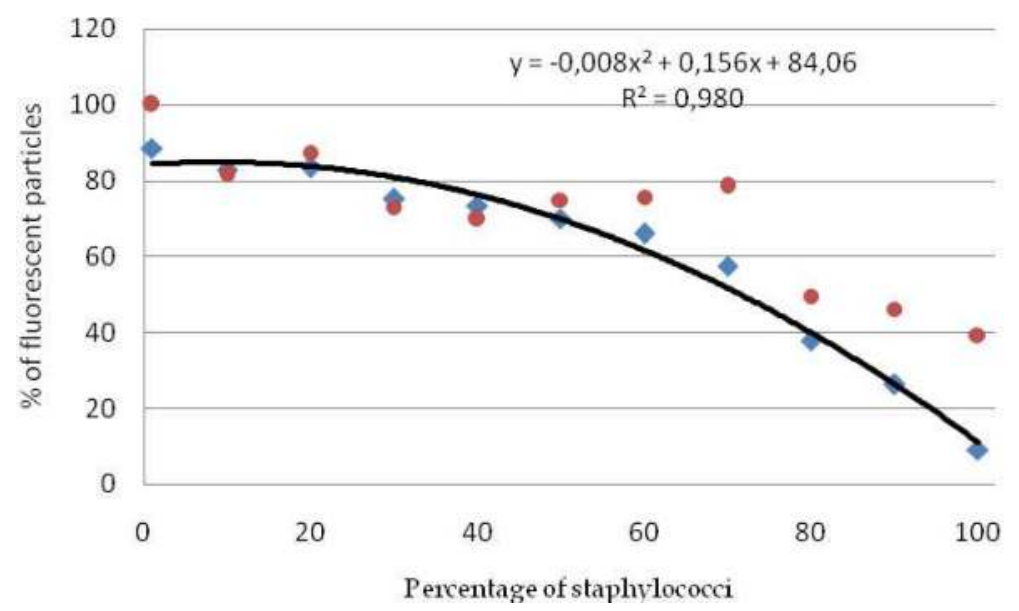

Fig. 8. Correlation between percentages of detectable particles in FLOW-FISH and proportion of E. faecalis cells in mixed culture stained by fluorescent 16sRNA probe

Detection of 16s RNA gene, which appeared to be successful in single cells, ranged between $10^{4}$ and $10^{5}$ ribosomes and, consequently, as many copies of 5S and 16Sand 23S-like rRNAs (Amman et al., 1990) making it was quite easy to get satisfactory signal. Despite the proven usefulness, serious limitations of FLOW- FISH technique in its sensitivity and resolution constitute an obstacle. It is believed that probes containing nucleic acid analogs with higher affinity for DNA and RNA may have the potential to reduce these problems (Kelly et al., 2009). An example of such probe is peptide nucleic acid (PNA), which binds to DNA and RNA with high affinity.

For our study, we decided to use another class of nucleic acid analogs in which the ribose sugar is constrained by a methylene bridge between 20-oxygen and 40-carbon, resulting in an N-type (3-endo) conformation, so called locked nucleic acids (LNAs) (Kelly et al., 2009).

LNA is able to hybridize with DNA and RNA according to Watson-Crick base-pairing rules and does so with unprecedented high affinity. As a result, LNAs have been shown to significantly improve the sensitivity and specificity. 
This technique is expected to be particularly useful for the detection of lower mRNA transcript levels. In fact, preliminary results (Fig. 9) are promising. On the other hand, further studies are needed for validation of chosen approach.

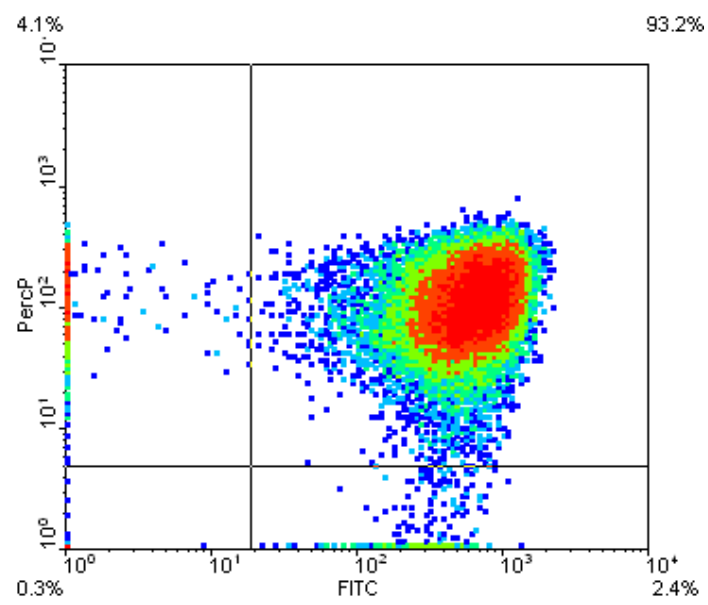

Fig. 9. Results of regulatory vancomycin gene detection with LNA probe (x axe- binding of probe, $\mathrm{Y}$ axe PI staining)

\section{Conclusion}

According to obtained results, fluorescent antibiotics are excellent tools both, for detection of resistance and studies of heteroresistance in flow cytometry. Model of vancomycin heteroresistance was successfully prepared and used in studies of clinical strains. Because it is believed that heteroresistance mechanism involves changes of cell structure, it is especially profitable in terms of antibiotic binding and changes in cell structure can be observed. However, overestimation of resistant cells in culture remain unsolved.

Preliminary results of FLOW-FISH are also promising. It seems, that use of LNA probes allows to express detection in single cells in culture. On the other hand, it is obvious that further studies are needed to evaluate the specifity ad sensitivity of this approach.

\section{Acknowledgment}

We thank Dr Agnieszka Daca and prof Ewa Bryl (Department of Physiopathology, Medical Unversity of Gdańsk) for their support of flow cytometry analysis of this study.

This study was supported by grants from: National Science CentreNN 401597540

\section{References}

Amann, R., I.; Binder, B.; Olson, R., J.; Chisholm, S., W.; Devereux, R.; Stahl, D.,A.(1990)' Combination of $16 \mathrm{~S}$ rRNA-Targeted Oligonucleotide Probes with Flow Cytometry 
for Analyzing Mixed Microbial Populations. Applied And Environmental Microbiology, 56, pp. 1919-1925

Alvarez-Barrientos, A.; Arroyo, J.; Canton, R.; Nombela, C.; Sanchez- Perez, M.(2000). Application of flow cytometry to clinical microbiology. Clin Microbiol Rev , 13, pp.167-195

Baptista, M.; Rodrigues, P.; Depardieu, F.; Courvalin, P.; Arthur, M.(1999) Single-cell analysis of glycopeptide resistance gene expression in teicoplanin-resistant mutants of a VanB-type Enterococcus faecalis. Molecular Microbiology , 32(1), pp. $17 \pm 28$

Barski, P.; Piechowicz, L.; Galiński, J.; Kur, J. (1996). Rapid assay for detection of methicillinresistant Staphylococcus aureus using multiplex PCR. Molec. Cellul. Probs., 10, pp. $471-475$

Bizzini, A.; Zhao, H.; Auffray, H., Hartke, A. The Enterococcus faecalis superoxide dismutase is essential for its tolerance to vancomycin and penicillin. Journal of Antimicrobial Chemotherapy, 64, pp. 1196-1202

Blair, J.E.; Williams, R.,E.,O. (1961). Phage typing of Staphylococci. Bull. World Health Organ, 24, pp. 771-784.

Cargill, S.; Upton, L. (2003). Low concentrations of vancomycin stimulate biofilm formation in some clinical isolates of Staphylococcus epidermidis. Curr. Issues Mol. Biol., 5, pp. 9-15.

Clinical and Laboratory Standards Institute. 2006. Performance standards for antimicrobial susceptibility testing; sixteenth informational supplement., Vol. 26, No. 3.

Davey, H.; Winson, M. (2003). Using Flow Cytometry to Quantify Microbial Heterogeneity Curr. Issues Mol. Biol., 5, pp. 9-15

De Lencastre, H.; Figueiredo, A.; Tomasz,. A. (1993). Genetic control of population structure in heterogeneous strains of methicillin resistant Staphylococcus aureus. Eur J Clin Microbiol Infect Dis , 12, pp. 13-18

Device , O.; Toshiro, S.; Akinobu, Gotoh.; Yutaka, K.; Satoru , Muto.; Hisamitsu, I.; Yukio, H.; Horie, S.(2006). Enumeration of Bacterial Cell Numbers and Detection of Significant Bacteriuria by Use of a New Flow Cytometry-Based Journal of Clinical Microbiology, pp. 3596-3599

Falagas, M., E.,; Makris, C., G., ; Dimopoulos, G.,; Matthaiou, D., K. (2008). Heteroresistance: a concern of increasing clinical significance? Clin Microbiol Infect , 14, pp 101-104

Fiebelkorn, K.,R.; Crawford, S.,A.; Mc Elmeel, M.,L.; Jorgensen, J.,H. et al. (2003). Practical disc diffusion method for detection of inducible clindamycin resistance in Staphylococcus aureus and coagulase- negative staphylococci. J. Clin. Microbiol., 41, pp. 4740-4744.

Finan, J., E.; Rosato, A.,E.; Dickinson, T.,M.; Ko, D.; Archer, G.,L. (2002). Conversion of oxacillin-resistant staphylococci from heterotypic to homotypic resistance expression. Antimicrob Agents Chemother, 46, pp. 24-30

Frebourg, N., B.; Nouet, D.; Lemée, L.; Martin , E; Lemeland, J.,F.(1998). Comparison of ATB staph, rapid ATB staph, Vitek, and E-test methods for detection of oxacillin 
heteroresistance in staphylococci possessing mecA. Clin Microbiol. , (Jan 1998) 36, (1) pp. 52-7..

Gazzola, S.; Cocconcelli, P., S. (2008). Vancomycin heteroresistance and biofilm formation in Staphylococcus epidermidis from food. Microbiology, 154, pp. 3224-3231

Gunasekera, T., S.; Attfield, P.,V.; Veal, D.,A.(2000). A flow cytometry method for rapid detection and enumeration of total bacteria in milk. Applied and Environmental Microbiology, 66, pp.1228-1232.

Hartman, B., J.; Tomasz, A. (1986). Expression of methicillin resistance in heterogeneous strains of Staphylococcus aureus. Antimicrob Agents Chemother, 29, pp. 85-92

Harmsen, D.; Claus, H.; Witte, W.; Rothganger, J.; Turnwald, D. et al., (2003). Typing of methicillin-resistant Staphylococcus aureus in a university hospital setting by using novel software for spa repeat determination and database management. J. Clin. Microbiol., 41, pp. 5442-5448.

Hasman, H.; Aarestrup, FM.; Dalsgaard, A.;Guardabassi, L. (2006) Heterologous expression of glycopeptide resistance vanHAX gene clusters from soil bacteria in Enterococcus faecalis Journal of Antimicrobial Chemotherapy 57, 648-653

Jarzembowski, T.; Wiśniewska, K.; Jóź wik, A.; Bryl, E.; Witkowski ,J. (2008). Flow cytometry as a rapid test for detection of penicillin resistance directly in bacterial cells in Enterococcus faecalis and Staphylococcus aureus. Curr Microbiol, 57, pp. 167-169

Jarzembowski, T.; Wiśniewska, K.; Jóź wik, A.; Witkowski ,J. (2009). Heterogeneity of Methicillin-Resistant Staphylococcus aureus Strains (MRSA) Characterized by Flow Cytometry, Curr Microbiol, 59, pp. 78-80

Jarzembowski, T.; Wiśniewska, K.; Jóź wik, A.; Witkowski ,J. (2010). Flow Cytometry Approach Study of Enterococcus faecalis Vancomycin Resistance by Detection of Vancomycin@FL Binding to the Bacterial Cells. Curr Microbiol , 61, pp. 407-410

Kelly, L.; Robertson, A.; Dzung, C., Thach, C.(2009). LNA flow-FISH: A flow cytometryfluorescence in situ hybridization method to detect messenger RNA using locked nucleic acid probesAnalytical Biochemistry. 390, pp. 109-114

Kobayashi, N.; Urasawa, S.; Uehara, N.; Watanabe, N.(1999). Analysis of genomic diversity within the Xr-region of the protein A gene in clinical isolates of Staphylococcus aureus. Epidemiol. Infect., 122, pp. 241-249.

Mansour JD, Robson JA, Arndt CW, Schulte Detection of Escherichia coli in Blood Using Flow Cytometry. Cytometry, 6, pp. 186-190

Markova, N.; Haydoushka, I.; Michailova, L.; Ivanova, R.; Valcheva, V.; Jourdanova, M.; Popova, T.; Radoucheva, T. (2008). Cell wall deficiency and its effect on methicillin heteroresistance in Staphylococcus aureus.International Journal of Antimicrobial Agents , 31, pp. 255-260

National Committee for Clinical Laboratory Standards (2002). Methods for dilution antimicrobial susceptibility tests for bacteria that grow aerobically. 5th edn. Approved standard M7-A5. National Committee for Clinical Laboratory Standards, Wayne,PA

Nunes, A., P., F.; Schuenck, R., P.; Bastos, C., C.; Magnanini, M., M., F.; Long, J., B.; Iorio, N.; Netto dos Santos, K., R.(2007). Heterogeneous resistance to vancomycin and 
teicoplanin among Staphylococcus spp. isolated from bacteremia. Brazilian Journal of Infectious Diseases, vol.11, no.3 (June 2007).

Nottasorn, P.; Gilat, L.; Heidi, B.; Thomson, R. (2005). Unstable vancomycin heteroresistance is common among clinical isolates of methiciliin-resistant Staphylococcus aureus Journal of clinical microbiology, Vol. 43, No. 5,( May 2005), pp. 2494-2496

Okuma, K.; Iwakawa , K.; Turnidge, J., D. et al (2002). Dissemination of new methicillinresistant Staphylococcus aureus clones in the community. J Clin Microbiol, 40, pp. 4289-4294

Périchon, B., Courvalin, P.(2006). Synergism between _-Lactams and Glycopeptides against VanA-Type Methicillin-Resistant Staphylococcus aureus and Heterologousn Expression of the vanA Operon. Antimicrobial agents and chemotherapy, Vol. 50, No. 11 (Nov. 2006), pp. 3622-3630

Richardson, J.,F.; Rosdahl, V.,T.; van Leeuwen, W.,J.; Vickery, A.,M.; Vindel, A. et al. (1999).Phages for methicillin-resistant Staphylococcus aureus: an international trial. Epidemiol. Infect., 122, pp. 227-233.

Rupptisch, W.; Indra, A.; Stoger, A. et al. (2006). Classifying spa types in complexes improves interpretation of typing results for methicillin-resistant Staphylococcus aureus.J. Clin. Microbiol., 44, pp. 2442-2448.

Sakoulas, G.; Gold, H.,S.;Venkataraman, L.; Degirolami, P., C.; Eliopoulos, G., M. Qian, Q. (2001). Methicillin-Resistant Staphylococcus Aureus: Comparison Of Susceptibility Testing Methods And Analysis Of Meca-Positive Susceptible Strains. Journal Of Clinical Microbiology, 39, vol 11, pp. 3946-3951.

Saribas, S; Bagdatli, Y.(2004). Vancomycin tolerance in enterococci. Chemotherapy, 50, pp. 250-4.

Takashi, S.; Yoshitsugu, I.; Shunji, T.; Naoko, F.; Junya, I.; Yukio, H.; Satoshi, I.(2005). Feasibility of flow cytometry for the detection of bacteria from body fluid samples. J Infect Chemother, 11, pp. 220-225

Troussellier, M.; Courties, P.; Servais, P. (1999).Flow cytometric discrimination of bacterial populations in seawater based on SYTO 13 staining of nucleic acids. FEMS Microbiology Ecology, 29, pp. 319-330

Wannet, W., J. Spread of an MRSA clone with heteroresistance to oxacillin in the Netherlands. Euro Surveill. 2002;7(5):pii=367. Available online: http:/ / www.eurosurveillance.org/ViewArticle.aspx?ArticleId=367

Wong, S.,S.,Y.; Ho, P.,L.; Woo, P.,C.,Y.; Yuen, K.,Y. (1999)Bacteremia caused by staphylococci with inducible vancomycin heteroresistance. Clin Infect Dis ,29, pp. 760-7.

Waar, K.; Degener, J.,E.; van Luyn, M., J.; Harmsen, H.,J.(2005) Fluorescent in situ hybridization with specific DNA probes offers adequate detection of Enterococcus faecalis and Enterococcus faecium in clinical samples. J Med Microbiol., 54, pp. 93744.

Zhao, G.; Meier, T., I.; Kahl, S., D.; Gee, K., R.; Blaszczak, L.,C. (1999). Bocillin fl, a sensitive and commercially available reagent for detection of penicillin-binding proteins. Antimicrob Agents Chemother, 43, pp. 1124-1128 
Zwirglmaier, K.; Ludwig, W.; Schleifer, K.,H.(2004). Recognition of in dividual $g$ enes in a single bacterial cell by fluorescence in situ hybridization - RING-FISH Molecular Microbiology , 51, vol 1, pp. 89-96 


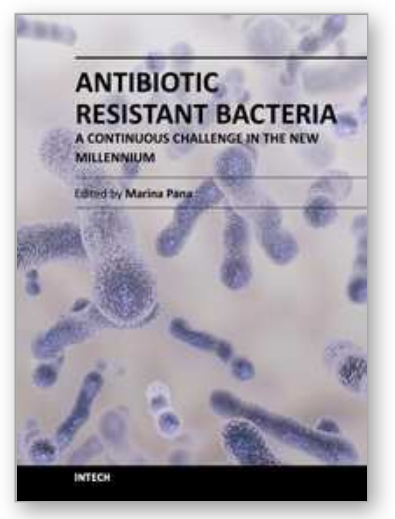

\section{Antibiotic Resistant Bacteria - A Continuous Challenge in the New Millennium}

Edited by Dr. Marina Pana

ISBN 978-953-51-0472-8

Hard cover, 576 pages

Publisher InTech

Published online 04, April, 2012

Published in print edition April, 2012

Antibiotic-resistant bacterial strains remain a major global threat, despite the prevention, diagnosis and antibiotherapy, which have improved considerably. In this thematic issue, the scientists present their results of accomplished studies, in order to provide an updated overview of scientific information and also, to exchange views on new strategies for interventions in antibiotic-resistant bacterial strains cases and outbreaks. As a consequence, the recently developed techniques in this field will contribute to a considerable progress in medical research.

\section{How to reference}

In order to correctly reference this scholarly work, feel free to copy and paste the following:

Tomasz Jarzembowski, Agnieszka Jóźwik, Katarzyna Wiśniewska and Jacek Witkowski (2012). Single Cell Level Survey on Heterogenic Glycopeptide and $\beta$-Lactams Resistance, Antibiotic Resistant Bacteria - A Continuous Challenge in the New Millennium, Dr. Marina Pana (Ed.), ISBN: 978-953-51-0472-8, InTech, Available from: http://www.intechopen.com/books/antibiotic-resistant-bacteria-a-continuous-challenge-in-thenew-millennium/single-cell-level-survey-on-heterogenic-glicopeptide-and-lactams-resistance

\section{INTECH}

open science | open minds

\section{InTech Europe}

University Campus STeP Ri Slavka Krautzeka 83/A 51000 Rijeka, Croatia Phone: +385 (51) 770447

Fax: +385 (51) 686166 www.intechopen.com

\section{InTech China}

Unit 405, Office Block, Hotel Equatorial Shanghai No.65, Yan An Road (West), Shanghai, 200040, China 中国上海市延安西路65号上海国际贵都大饭店办公楼 405 单元 Phone: +86-21-62489820

Fax: +86-21-62489821 
(C) 2012 The Author(s). Licensee IntechOpen. This is an open access article distributed under the terms of the Creative Commons Attribution 3.0 License, which permits unrestricted use, distribution, and reproduction in any medium, provided the original work is properly cited. 